UDC $630 * 228.8: 582.632(477-924.52): 630 * 182.9$

\title{
SIMULATION OF BEECH STAND DYNAMICS UNDER CLIMATE CHANGE CONDITIONS IN THE CARPATHIANS AND ROZTOCZE USING FORKOME MODEL
}

\author{
Ihor Kozak1, Taras Parpan², Hanna Kozak' \\ ${ }^{1}$ John Paul II Catholic University of Lublin, Konstantynov 1H, 20-708, Lublin, Poland \\ ${ }^{2}$ Ukrainian Research Institute of Mouintain Forestry \\ 31, Hrushevskyi St., Ivano-Frankivsk 76018, Ukraine \\ e-mail: tarasparpan@gmail.com
}

This paper presents a computer prognostic modeling of the beech (Fagus sylvatica L.) forests dynamics in the Carpathians and Roztocze using FORKOME model. The study was conducted in the Polish Bieszczady (Stuposiany forestry), Ukrainian Beskidy (Nadsanski Landscape Park) and in Polish Roztocze (Roztoczanski National Park) regions. The aim of this study was to carry out prognosis of possible dynamics of beech stands in Carpathians and Roztocze using computer model. For this purpose, a computer prognostic FORKOME model has been applied. Different scenario of changes were included: a control scenario, warm dry, warm humid, cold dry and cold humid. The simulations were realized for a time period covering next 500 years. Using the control scenario, FORKOME model predicted that for the next 500 years beech stands will dominate in terms of biomass and number of trees. The results have confirmed the periodic tendency of changes in stands consisting of biomass participation exchange between beech and fir. The obtained results are important issues for forest management and prognosis.

Key words: prognosis, computer, modelling, forest, temperature, precipitation.

\section{INTRODUCTION}

Computer models application in ecology allows the prediction of the behavior of complex systems to which forest ecosystems belong [18]. However, taking into account the specific condition and arrangement of forests, the examination of their dynamics requires the use of particular tools [1]. This role may be fulfilled by - adequately constructed - models of forest dynamics. The two existing methods of forest modelling, growthyield modelling $[13,17]$ and ecological modelling $[1,3,19]$ devolved independently over a long period, both competing and complementing each other. Most existing forest growth-yield models focus on wood production and are not concerned with other aspects of the forest environment. Most empirical growth-yield models based on permanent plot data implicitly assume that the future will be like the past, in terms of most environmental factors. This models are widely used in forestry, while the formerly widespread tabular statement of their results is now replaced by the corresponding regression models or integrated computer models of trees, such as SILVA [17] or BWINPro [13].

ISSN 1996-4536 (print) • ISSN 2311-0783 (on-line) • Біологічні Студії / Studia Biologica • 2016 • Том 10/№1 • C. 123-132 
Ecological (process) models provide reasonable results reflecting the projected state of the environment. There is linked to it a wide field of applications of process models which relate both to the betterunderstanding of the major biological processes that underpin the trees, as well as to forecasting the development of structurally complex natural stands and stands that are influenced by changing environmental conditions (including the future climate change). Among the earliest computer models of the forest landscape there should be mentioned JABOWA model [4] and FORET model [20]. Among the later constructions of patch models of the forest, based on those archetypes, there were FORSKA [16], ZELIG [21], SORTIE [14] endothers. Descriptions of the theoretical and review of process models can be found in literature [15]. Bugmann [1] has presented an excellent overview on the gap model approach and the potential of ecosystem models to address the issue of climate change [2]. A pursuant of above-mentioned trend in modelling the evolution of forest ecosystems is the patch model FORKOME [10, 11]. The FORKOME model that contains elements of both ecological and growth yieldstrategy has been specially designed for the conditions of Poland and Ukraine.

The aim of the study was to carry out prognosis of possible dynamics of beech stands in Carpathians and Roztocze during the next 500 years with the use of FORKOME model. Different scenarios of changes were included: a control scenario, warm dry climate and warm humid climate, cold dry climate and cold humid climate.

Geographical setting. The study site "Beech 1" is located in the Carpathians in Polish Bieszczady (Stuposiany Forestry), "Beech 2" in Ukrainian Beskidy (Nadsians'ki Regional Landscape Park), and "Beech 3" in the Polish Roztocze (Roztoczański Nature Park). The first plot - "Beech 1" islocated in the forest district No. 13a in the Stuposiany Forestry $\left(49^{\circ} 11^{\prime} 23^{\prime \prime} \mathrm{N}, 22^{\circ} 38^{\prime} 39^{\prime \prime} \mathrm{E}\right)$, Poland. The second plot - "Beech 2" is located in the forest district No. 3 in Jabluneckie Forestry in Nadsians'ki Regional Landscape Park $\left(49^{\circ} 09^{\prime} 47^{\prime \prime} \mathrm{N}, 22^{\circ} 45^{\prime} 15^{\prime \prime} \mathrm{E}\right)$, Ukraine. The third plot - "Beech 3" is located in the forest district No. $189 \mathrm{f}$ in the Roztoczanski National Park (N: 50³5'29 E: $\left.22^{\circ} 57^{\prime} 35\right)$ in Poland.

\section{MATERIALS AND METHODS OF THE RESEARCH}

Beech (Fagussylvatica L.) and fir (Abiesalba Mill.) has dominated in all the investigative areas. The mean DBH (diameter at breast height) for the plot "Beech 1" $-48.8 \mathrm{~cm}$ (max 120, min 6, standard deviation 38.2), for "Beech 2" - $27.1 \mathrm{~cm}(\max 103$, min 4, standard deviation 27.8) and 41,1 cm (max 104, min $10 \mathrm{~cm}$, standard deviation 33.4) for the plot "Beech 3". All the research areas were facing east and the ground slope was $5-12^{\circ}$. Statistical analyses of measurement of trees on the plots were performed using STATISTICA software. In all three areas, DBH values are coming to form a normal, right-skewed distribution (Shapiro-Wilk test). Each research area was a $50 \times 50 \mathrm{~m}$ rectangle. Such area $\left(2500 \mathrm{~m}^{2}\right)$ is appropriate for gap models.

Each research area was constructed using standard measuring tape to establish a rectangular coordinate system ( $X$ axis along $\mathrm{E}-\mathrm{W}$ and $\mathrm{Y}$ axis along $\mathrm{N}-\mathrm{S}$ line). Each and every tree within such established research area was assigned a unique number and measure ( $\mathrm{DBH}$, height, crown radius, age). The position of every tree was also established at $5 \mathrm{~cm}$ accuracy and then marked on a map using orthogonal survey method. The age was established with the help of Pressler drill. The diameter at breast height was measured using a dedicated meter at $1.3 \mathrm{~m}$ over the ground level. The tree height was measured with LeissBL8 height-meter. In order to verify leaf area index (LAI) calculations, 9 hemispherical photographs were taken per research area (camera Canon EOS 5D 12MP, Sigma $8 \mathrm{~mm}$ f/3.5 DG FISH EYE lens with $180^{\circ}$ viewing angle). The

ISSN 1996-4536 (print) • ISSN 2311-0783 (on-line) • Біологічні Студії / Studia Biologica • 2016 • Том 10/№1 • С. 123-132 
hemispherical photographs were analyzed with the help of the Gap Light Analyzer software [6]. Next, the obtained results were used to verify the FORKOME model input parameters (assimilation apparatus biomass). Selected data were stored in csv format (using Microsoft Excel spreadsheet) and supplied to the FORKOME model.

The influence of climate changes (total effective temperatures and total annual precipitation) on the rate of beech replacement by other species was also the subject of this study. To this end, "temperature changes scenario" and "precipitation changes scenario" tools were used. No climate change scenario was used as control (1425 degree days on "Beech 1"; 1420 degree days on "Beech 2"; 1400 degree days on "Beech 3"; $718 \mathrm{~mm}$ on "Beech 1"; $700 \mathrm{~mm}$ on "Beech 2"; $600 \mathrm{~mm}$ on "Beech 3"). Next, the following climate change scenarios are defined:

- warm humid: temperature increase by 200 degree days and increase in precipitation by $100 \mathrm{~mm}$,

- warm dry: temperature increase by 200 degree days and decrease in precipitation by $100 \mathrm{~mm}$,

- cold humid: temperature decrease by 200 degree days and increase in precipitation by $100 \mathrm{~mm}$,

- cold dry: temperature decrease by 200 degree days and decrease in precipitation by $100 \mathrm{~mm}$.

Model FORKOME [11] was constructed with an aim to simulate the dynamics in foreststands considering the fate of single trees (Fig. 1).

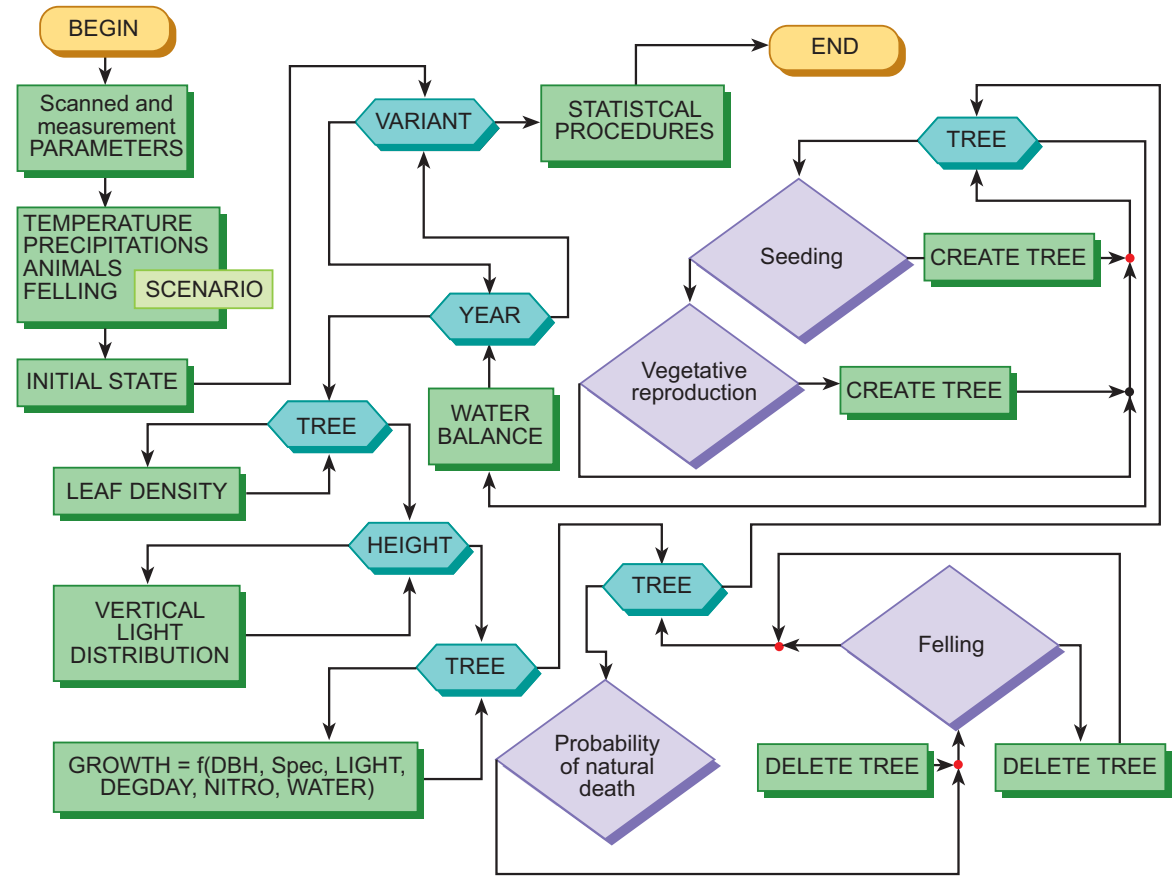

Fig.1.The algorithm of the FORKOME model

Рис. 1. Алгоритм моделі FORKOME

The model conducts simulation of reproductive processes (block BIRTH), growth (block GROWTH) and mortality (block DEATH) of trees during every year, as well as the 
influence of additional environmental and ecological factors upon the tree stand. Among the factors considered are annual sum of precipitation (block PRECIP), annual sum of temperatures effective DGD (degree days) for vegetation (block TEMP), nitrogen contents in the soil (block NUTRIENT), degree ofshading of the area (block LIGHT) by tree crowns [11]. All forested areas in the model are analyzed on the basis of the abovementioned blocks, consideringthe actual increase of $\mathrm{DBH}$ during the year of simulation (so-called DINC). DINC means an optimal increase of DBH, i.e. an increase of tree diameter in optimal conditions of environment. Hence, $\mathrm{DBH}$ is the fundamental parameter of trees on which the model FORKOME is based. Other significant parameters, e.g. the height of trees, are calculated on the basis of $\mathrm{DBH}$ value (in case when real data ismissing). However, the actual increase of trees DINC has to take into account environmental conditions (annualsum of temperatures effective for vegetation; water balance connected with precipitation and transpiration; an averagelevel of light availability in the forest; availability of nitrogen in the forest litter) which may reduce an optimalincrease of DBH (DNC). Depending on dominating environmental conditions, every factor decreasing the optimalgrowth may take values between 0 and 1 .Every reducing factor is represented by an appropriate thematic block. Since the time of its creation until now, the FORKOME model is constantly revised. Possibly the most recent achievements in the field of landscape modelling are implemented. This model was already used in scientific projects in various regions of Poland, Ukraine and Sweden.Model FORKOME also contains continuously developed presentation layer, which allows for 3D visualization of components of the forest landscape, including the layer of ground vegetation, dried and fallen trees.

\section{RESULTS AND DISCUSSION}

Diagrams presenting results of prognosis of plots 1 - "Beech 1", 2 - "Beech 2", and 3 - "Beech 3" are placed in the paper under the control scenario, as well as in 4 climate changes scenarios. We carried out simulations with the FORKOME model in 3 research areas of $50 \times 50 \mathrm{~m}(1 / 4 \mathrm{ha})$ each. Therefore, within the $2500 \mathrm{~m}^{2}$ area, 200 simulation sequences correspond with equilibrium landscape of 50 ha. In other types of models, for instance the JABOWA model [4], 10×10 m areas were used with 100 simulations. The smallest area was 0,5 ha and was used in the FORSKA model [16].

Analyses of the diagrams indicate that under the control scenario in the first year of simulation beech dominated in all plots. Beech biomass will dominate during the period predicated at 90 years on the plot 1 (Fig. 2, A), 110 years on the plot 2 (Fig. 2, B) and 140 years on the plot 3 (Fig. 2, C). In the next time fir will dominate for 100 years on the plot 1 , for 200 year on the plot 2 and for several years on the plot 3 , than beech is going to dominate again. In the control scenario cyclical changes between beech and fir are more visible in the Carpathians region than in Roztocze. In plot 1 beech biomass increases to $700 \mathrm{t} / \mathrm{ha}$, and in the other plots, i.e. 2 and 3, beech biomass will increase to 400 and 640 t/ha. However, inconsiderabledomination of beech biomass occurs at the end of prognosis time (Fig. 2, $A ; 2, B$ ) and interrupted of fir dominating from 300 to 400 year on the plot 3 (Fig. 2, C). Other species as sycamoreincreases up to $180 \mathrm{t} / \mathrm{ha}$ (Fig. 2, B), spruce up to 90 t/ha in biomass (Fig. 2, A; 2, B), hornbeam and oak (Fig. 2, C) fragmentary presented.

In Carpathians and Roztocze beech and fir will maintain its domination regarding biomass not only in the control scenario, but also in warm humid, warm dry, cold humid and cold dry climate scenario. Beech and fir have optimal growing conditions in Carpathians and Roztocze.

ISSN 1996-4536 (print) • ISSN 2311-0783 (on-line) • Біологічні Студії / Studia Biologica • 2016 • Том 10/№1 • С. 123-132 

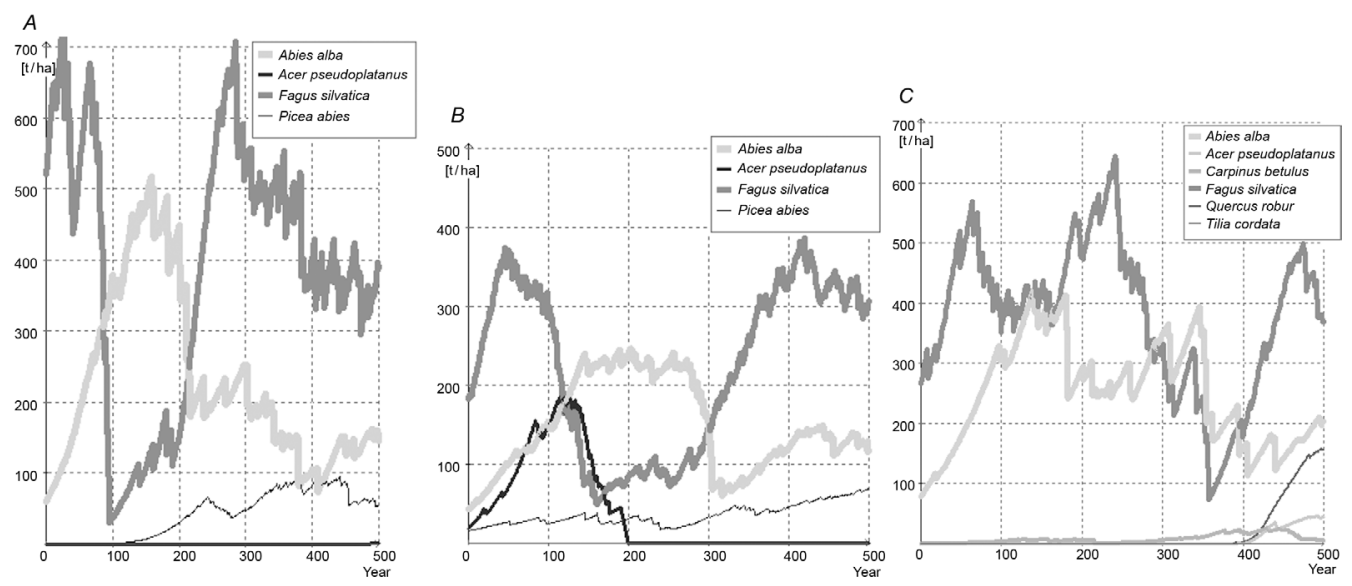

Fig. 2. Prediction of beech stands biomass in control scenario (t/ha): $A$ - Beech 1; $B$ - Beech 2; $C$ - Beech 3

Рис. 2. Прогноз біомаси букового деревостану в контрольному сценарії (т/га): $A$ - Бук $1 ; B$ - Бук 2 ; $C$ Бук 3

In warm humid scenario beech biomass increases up to $900 \mathrm{t} /$ ha on the plot 1 , to 740 t/ha on the plot 2 and to 610 t/ha on the plot 3.On the plot 3 in Roztocze beech will dominate during the whole simulation (Fig. 3, C).
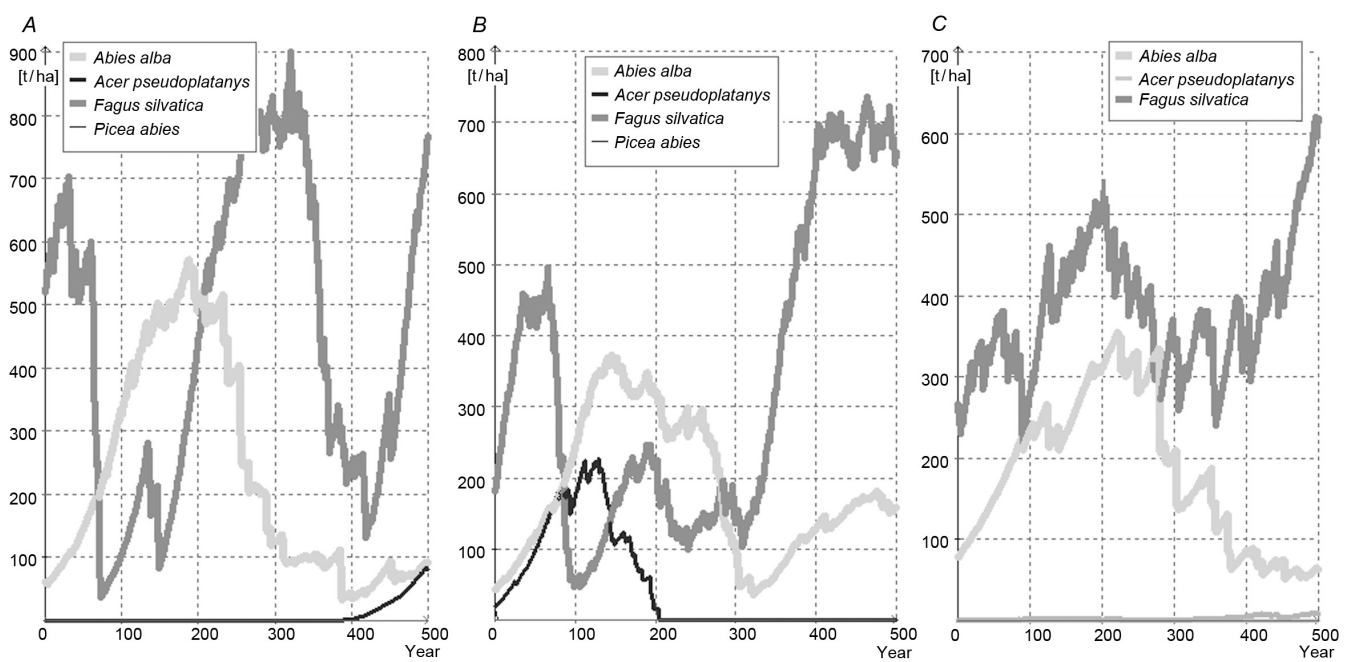

Fig. 3. Prediction of beech stands biomass in warm humid scenario (t/ha): $A-$ Beech $1 ; B-$ Beech 2 ; $C-$ Beech 3.

Рис. 3. Прогноз біомаси букового деревостану за сценарію “тепло-волого” (т/га): $A$ - Бук 1; $B$ - Бук 2; C-Бук 3 .

In warm dry scenarios beech will dominated, but biomass decreased. On the plot 3 in Roztocze beech biomass will decrease to 200 t/ha (Fig. 4, C).

In cold humid scenario (Fig. 5) fir biomass increases up to 700 t/ha (Fig. 5, A). In the Carpathians there occurs possible increase of spruce biomass (Fig. $5, A ; 5, B$ ). 

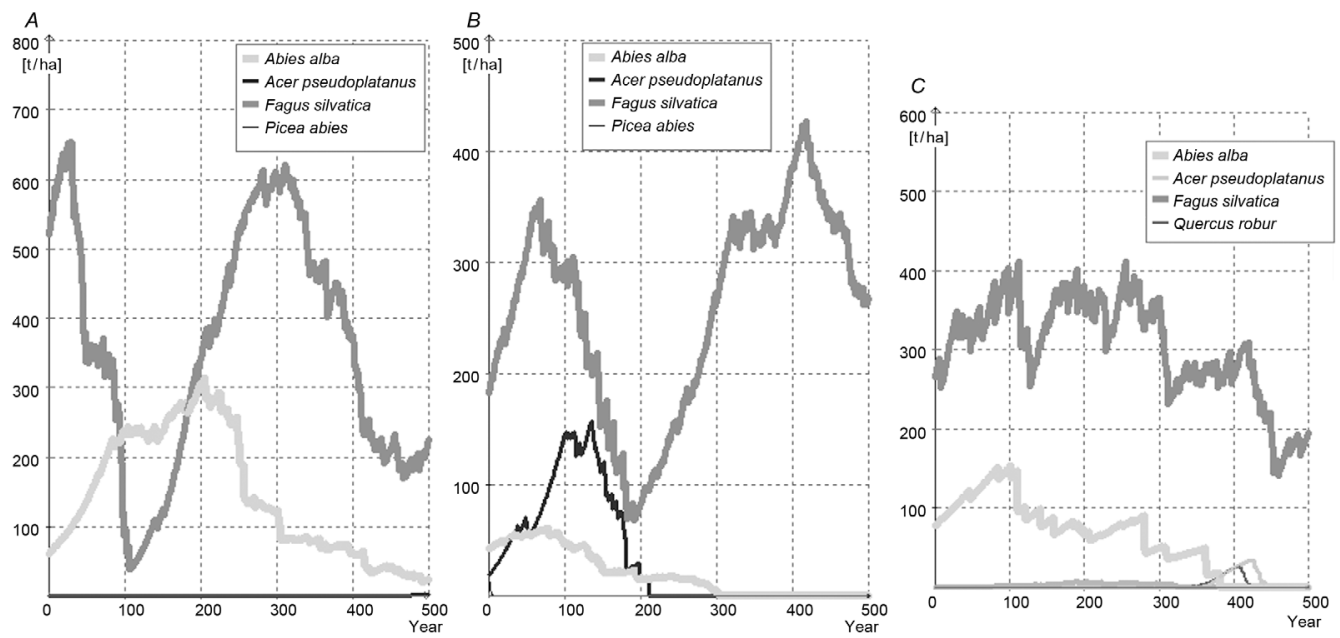

Fig. 4. Prediction of beech stands biomass in warm dry scenario (t/ha): $A-$ Beech $1 ; B-B e e c h 2 ; C-$ Beech 3

Рис. 4. Прогноз біомаси букового деревостану за сценарію “тепло-сухо” (т/га): $A$ - Бук 1 ; $B$ - Бук 2; C Бук 3
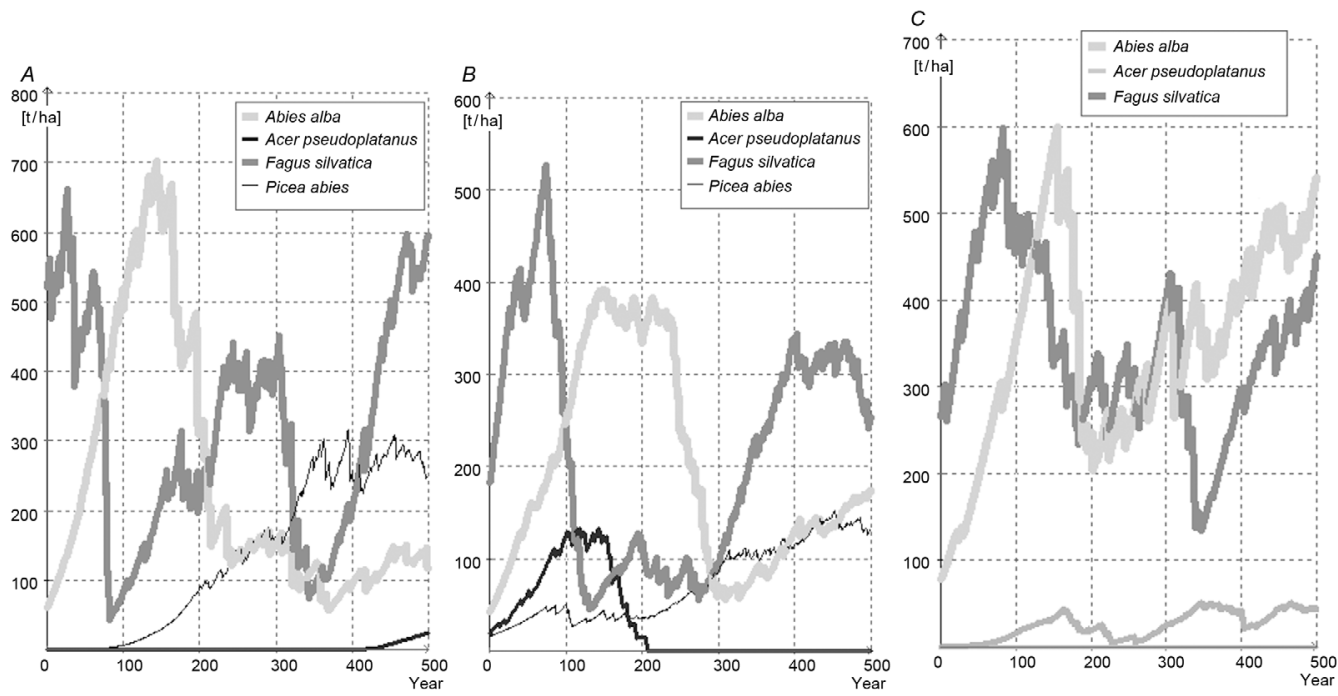

Fig. 5. Prediction of beech stands biomass in cold humid scenario (t/ha): $A-$ Beech $1 ; B-$ Beech $2 ; C-$ Beech 3

Рис. 5. Прогноз біомаси букового деревостану за сценарію “холодно-волого” (т/га): $A$ - Бук 1 ; $B$ - Бук 2; C- Бук 3

In cold dry scenario (Fig. 6) the beech biomass decreased up to 100 t/ha on the 1 and 3 research plots. On the plot 2, beech biomass decreases while biomass of sycamore increases. Fir biomass will dominate in Roztocze in the second part of simulation (Fig. 6, C).

The FORKOME model is a good enable to obtain results that prove the thesis assumed in our paper that the changes of temperature and precipitation can (as we see 
from simulations) conduct to different reaction of tree. There may occurweakening of cyclical changes between beech and fir biomass dynamic and decrease in biomass or change of the stand structure. Results obtained from the prediction research correspond to results obtained from field works and this phenomenon described in literature $[9,10]$.
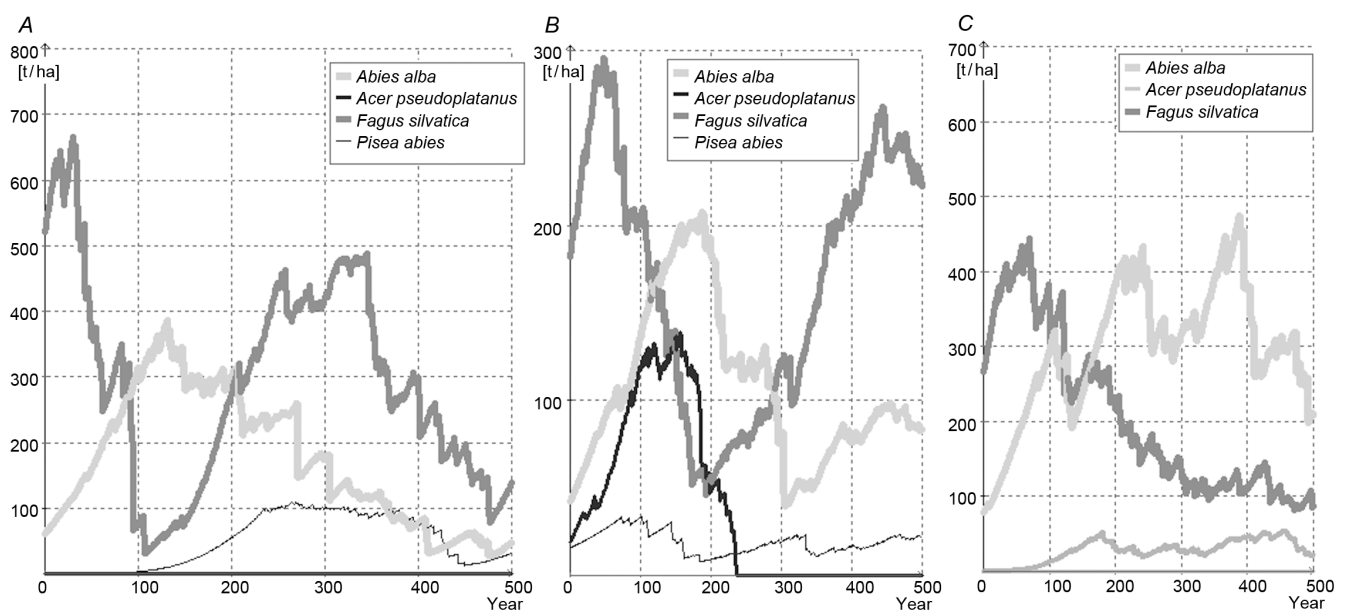

Fig. 6. Prediction of beech stands biomass in cold dry scenario (t/ha): $A$ - Beech 1; B-Beech 2; $C$ - Beech 3

Рис. 6. Прогноз біомаси букового деревостану за сценарію "холодно-сухо" (т/га): $A$ - Бук 1 ; $B$ - Бук 2 ; С-Бук 3

The FORKOME model proved to be an efficient tool adjusted to the research regarding dependences and changes in species structure of forest stands, species biomass, and number of trees. It is possible to apply methods in the model to analyze many parameters of forest stands conditions at the same time what allows for obtaining precise results. The FORKOME model enables analyzing the dynamics of forest stands in regard to climate change conditions during any period of time, chosen by the user of the model (for example, 500 years). Obtained simulation results concerning temperature and precipitation can influence the species composition of tree stands and decrease the regeneration and growth of other species [7].

In the cold dry scenario we can notice a decrease in beech biomass more in Roztocze than in the Carpathians. At the same time we can expect a decrease in biomass of other species sensitive to water deficiency.

Simulation conducted in FORKOME model confirms that beech will exist in the Carpathians and Roztocze regions on the east boundary of beech areal. Using computer models for such type of analysis is a current aimed perspective trend [5]. Important is the analysis of temperature and precipitation influence on beech stands. Beech biomass is more sensitive to the precipitation than to the temperature. Precipitation can decrease growth rate up to 0.82 . Calculated in FORKOME model cross correlation showed negative influence of precipitation on beech biomass (correlation coefficientis -0.95). Climate changes in the Carpathians and Roztocze can be estimated as a positive factor for forest productivity and biomass accumulations. Similar results obtained for north and west Europe [12]. Beech stands in Carpathians and Roztocze regions have plausibility and delay in stand composition changes due to climate changes [8].

Longer (500 years) time of simulation was used to shown the cycle of biomass changes that were demonstrated in the literature [19]. In the other regions simulation

ISSN 1996-4536 (print) • ISSN 2311-0783 (on-line) • Біологічні Студії / Studia Biologica • 2016 • Том 10/№1 • С. 123-132 
time was 500 and 600 years [10]. The changes in beech stands biomass in computer simulations with the use of FORKOME model define their directions regarding possible climate change conditions in the Carpathians and Roztocze and are important issues in forest management, both from the theoretical and practical perspective.

Dynamics of forests changes in mountainous areas have a multitude of functions: they regulate run-off and prevent erosion; they form a part of the largest terrestrial biotic carbon pool. Forests in the Carpathians and Roztocze have been managed for timber production over several centuries. After World War II forest use in Polish Bieszczady and Polish Roztocze was less active due to depopulation that was realized by Polish communist government in the operation with cryptonymous "Vistula". In Ukrainian Beskids that are situated in the similar ecological conditions as Polish Bieszczady the forest management activity in the Soviet Union time was more active, what influenced on the future decrease of biomass accumulation.

\section{CONCLUSIONS}

Results predicting the dynamics of beech forests in the Carpathian Mountains and Roztocze using computer model FORKOME are considered.

In the Carpathians and Roztocze beech and fir will maintain its domination regarding biomass in the control scenario, warm humid, warm dry, cold humid and cold dry climate scenario. Some cyclical changes between beech and fir are shown in the control scenario. In warm humid and warm dry scenario FORKOME model predicts possible weakening of cyclical changes between beech and fir biomass dynamic and increase in beech biomass. In cold humid scenario fir biomass increases up to $700 \mathrm{t} / \mathrm{ha}$. In the Carpathians, a possible increase in spruce biomass may occur. In cold dry scenario the beech biomass decreased up to $100 \mathrm{t} / \mathrm{ha}$.

Simulation conducted in FORKOME model confirms that beech will exist in the Carpathians and Roztocze regions on the east boundary of beech areal. Climate changes in Carpathians and Roztocze can be seen as a positive factor for forest productivity and biomass accumulations. Beech stands in the Carpathians and Roztocze regions demonstrate a plausibility and delayin stand composition changes due to climate change and are more sensitive to the precipitation than to temperature.

Changes in beech stands biomass in computer simulations with the use of FORKOME model define their directions regarding possible climate change conditions in Carpathians and Roztocze and are important issues in forest management, both from the theoretical and practical perspective.

Acknowledgements. We would like to appreciate Yurij Shparyk and Roman Viter from Vasyl Stefanyk Precarpathian National University for assistance in data collection and consultations.

1. Bugmann H. A review of forest gap models. Climatic Change, 2001, 51: 259-305.

2. Bugmann H. Predicting the ecosystem effects of climate change. In: Canham, C.D., Lauenroth, W. K. \& Cole, J.S. (eds.). Models in ecosystem science. Princeton University Press, Princeton, 2003, p. 385-409.

3. Botkin D.B. Forest Dynamics: An Ecological Model. Oxford, New York, Oxford University Press, 1993. 309 p.

4. Botkin D.B., Janak J.F., Wallis J.R. Some Ecological Consequences of a computer Model of Forest Growth. Journal of Ecology, 1972; 60(3): 849-872.

ISSN 1996-4536 (print) • ISSN 2311-0783 (on-line) • Біологічні Студії / Studia Biologica • 2016 • Том 10/№1 • С. 123-132 
5. Brooker R., Travis J., Clark E.J., Dytham C. Species' range shifts in a changing climate: The impacts of biotic interactions, dispersal distance and the rate of climate change. J. Theor. Biol, 2007; 245: 59-65.

6. Frazer G.W., Canham C.D., Lertzman K.P. Gap Light Analyzer (GLA), Version 2.0: Image processing software to analyze true-colour, hemispherical canopy photographs. Bulletin Ecological Society of America, 2000; 81: 191-197.

7. Gessler A., Keitel K., Kreuzwieser J. et al. Potential risks for European beech (Fagus sylvatica L.) in a changing climate. Trees, 2007; 21(1): 1-11.

8. Dale V.H., Tharp M.L., Lannom K.O., Hodges D. Modelling transient response of forests to climate change. Science of the Total Environ, 2010; 408: 1888-1901.

9. Jaworski A., Podlaski R. Construction, structure and dynamics of natural stands in Reserve Święty Krzyż. ActaAgraria et Silvestria. Ser. Silvestris, 2006; 44: 9-38. (In Polish).

10. Kozak I., Menshutkin V. Prediction of beech forests succession in Bieszczady Mountains using a computer model. Journal of Forest Science, 2001; 47(8): 333-339.

11. Kozak I., Mikusiński G., Stępień A. et al. Forest dynamics in a nature reserve: a case study from south-central Sweden. Journal of Forest Science, 2012; 58(10): 436-445.

12. Lindner M., Maroschek M., Netherer S. et al. Climate change impacts, adaptive capacity, and vulnerability of European forest ecosystems. For. Ecol. Manage, 2010; 259(4): 698-709.

13. Nagel J., Schmidt M. The Silvicultural Decision Support System BWINPro. In: Hasenauer H. (ed.): Sustainable Forest Management. Berlin, Springer, 2006, 59-63.

14. Pacala S.W., Canham C.D., Silander J.A. Forest models defined by field measurements. The design of a northeastern forest simulator. Can. J. For. Res, 1993; 23: 1980-1988.

15. Porte A., Bartelink H.H. Modelling mixed forest growth: a review of models for forest management. Ecological Modelling, 2002; 150: 141-188.

16. Prentice I.C., Leemans R. Pattern and process and the dynamics of forest structure: a simulation approach. Journal of Ecology, 1990; 78: 340-355.

17. Pretzsch H., Biber P., Dursky J. The single tree based stand simulator SILVA: Construction, application and evaluation. Forest Ecology and Management, 2002; 162: 3-21.

18. Scheller R.M., Mladenoff D.J. An ecological classification of forest landscape simulation models: Tools and strategies for understanding broad-scale forested ecosystems. Landscape Ecology, 2007; 22: 491-505.

19. Shugart H.H. Theory of Forests Dynamics. New York: Springer, 1984. 278 p.

20. Shugart H.H., West D.C. Development of an Appalachian deciduous forest model and its application to assessment of the impact of the chestnut blight. Journal of Biogeography, 1977; 5: 161-179.

21. Urban D.L. A versatile model to simulate forest pattern: a user's guide to ZELIG version 1.0. Charlottesville, VA: University of Virginia, Environmental Sciences Department. Forest Ecology and Management, 1990; 42: 95-110.

\title{
МОДЕЛЮВАННЯ ДИНАМІКИ БУКОВИХ ДЕРЕВОСТАНІВ ЗА УМОВИ ЗМІНИ КЛІМАТУ В КАРПАТАХ І РОЗТОЧЧІ 3 ВИКОРИСТАННЯМ МОДЕЛІ FОRКОМЕ
}

\author{
І. І. Козак', Т. В. Парпан ${ }^{2}$, Г. Г. Козак' \\ ${ }^{1}$ Люблінський Католицький університет ім. Івана Павла II \\ Константинув 1Н, 20-708, Люблін, Польща \\ ²Український науково-дослідний інститут гірського лісівництва ім. П.С. Пастернака \\ вул. Грушевського, 31, Івано-Франківськ 76018, Україна \\ e-mail: tarasparpan@gmail.com
}

У статті прогнозовано динаміку букових (Fagus sylvatica L.) лісів у Карпатах і на Розточчі за допомогою комп'ютерної прогностичної моделі FORKOME. Дослі-

ISSN 1996-4536 (print) • ISSN 2311-0783 (on-line) • Біологічні Студії / Studia Biologica • 2016 • Том 10/№1 • С. 123-132 
дження проведено в польських Бещадах (лісгосп Ступосяни), Українських Бескидах (Надсянський ландшафтний парк) і в польській частині Розточчя (Розточанський національний парк). Метою цього дослідження було прогнозування можливої динаміки бучин у Карпатах і Розточчі з використанням комп'ютерної моделі. 3 цією метою була застосована комп'ютерна прогностична модель FORKOME. Різні сценарії зміни були застосовані: контрольнй сценарій (без змін), сценарії змін клімату на теплий сухий, теплий вологий, холодний сухий і холодний вологий. Моделювання було реалізоване протягом періоду часу, що охоплює найближчі 500 років. У контрольному сценарії модель FORKOME передбачила, що протягом наступних 500 років бучини будуть домінувати щодо біомаси та кількості дерев. Результати підтвердили тенденцію періодичної зміни в деревостанах біомаси бука та ялиці. Отримані результати є важливими для ведення лісового господарства і прогнозу.

Ключові слова: прогноз, комп'ютер, моделювання, ліс, температура, опади.

\title{
МОДЕЛИРОВАНИЕ ДИНАМИКИ БУКОВЫХ ДРЕВОСТОЕВ ПРИ ИЗМЕНЕНИИ КЛИМАТА В КАРПАТАХ И РАСТОЧЬЕ С ИСПОЛЬЗОВАНИЕМ МОДЕЛИ FОRКОМЕ
}

\author{
И. И. Козак', Т. В. Парпан², Г. Г. Козак \\ ${ }^{1}$ Люблинский Католический университет им. Ивана Павла II \\ Константинув 1Н, 20-708, Люблин, Польша \\ ${ }^{2}$ Украинский научно-исследовательский институт \\ горного лесоводства им. П.С.Пастернака \\ ул. Грушевского, 31, Ивано-Франковск 76018, Украина \\ e-mail: tarasparpan@gmail.com
}

Статья представляет собой исследование моделирования динамики буковых (Fagus sylvatica L.) лесов в Карпатах и Расточье, с использованием модели FORKOME. Исследование проводилось в польских Бещадах (лесхоз Ступосяны), Украинских Бескидах (Надсянский ландшафтный парк) и в польской части Расточья (Расточанский национальный парк). Целью данного исследования было проведение прогноза динамики бучин в Карпатах и Расточье с использованием компьютерной модели. С этой целью была применена компьютерная прогностическая модель FORKOME. Использовались различные сценарии изменений: контрольный (без изменений), изменения климата на теплый сухой, теплый влажный, холодный сухой и холодный влажный. Моделирование было реализовано в течение периода времени, охватывающего ближайшие 500 лет. В контрольном сценарии модель FORKOME прогнозировала, что в течение следующих 500 лет бучины будут доминировать по биомассе и количеству деревьев. Результаты подтвердили тенденцию периодического изменения в древостоях, состоящую из обмена между участием биомассы бука и пихты. Полученные результаты являются важными вопросами для ведения лесного хозяйства и прогноза.

Ключевые слова: прогноз, компьютер, моделирование, лес, температура, осадки.

Одержано: 24.11.2015

ISSN 1996-4536 (print) • ISSN 2311-0783 (on-line) • Біологічні Студії / Studia Biologica • 2016 • Том 10/№1 • С. 123-132 